ABSTRACT

Mapping the Regional Distribution of Theatre in Denmark. Three Different Approaches Based on Official Theatre Statistics

This article presents three different mappings of the regional distribution of theatre in Denmark. Together, the three mappings cover important aspects of a national theatre system: production (subsidy), distribution of performances and theatre consumption. All of them are based on official theatre statistics and should, as such, be considered authoritative credible mappings on which a cultural policy debate on the decentralization of theatre in Denmark could be based.

However, the article demonstrates that the three different mappings result in three different results regarding the regional distribution of theatre in Denmark. This adds complexity to the policy debates because no definite conclusions can be made. In addition, the methodological discussion in the article demonstrates that the existing data sets have severe limitations.

Keywords: regional distribution, theatre statistics, decentralization, theatre systems, Denmark, mapping.

BIOGRAPHY

Louise Ejgod Hansen is Associate Professor at the School of Communication and Culture, Aarhus University. Her main research areas are cultural policy research, qualitative audience research and theatre studies. She was engaged

in a research and development project with Scenekunstnetværket Region Midtjylland 2010-13 and is currently (2013-18) functioning as Project and Research Manager of the research-based evaluation of Aarhus as European Capital of Culture in 2017. draleh@dac.au.dk 


\section{Mapping the Regional Distribution of Theatre in Denmark. \\ Three Different Approaches Based on Official \\ Theatre Statistics}

\section{LOUISE EJGOD HANSEN}

This article presents a mapping of the geographical distribution of theatre in Denmark. The mapping is based on three different official theatre data bases that draw three different maps. This means that the mapping of the geographical distribution of theatre in Denmark can illustrate some of the general methodological challenges of mapping: the choices made cannot be seen as neutral and the result differs dependent on the data set. This is by no means a surprise to theatre academics; however, it is still important to reflect upon, especially when a seemingly neutral method like cultural mapping is used as an input in the political debate on the subject of the decentralization of theatre in Denmark

The article presents three different mappings: one focusing on the subsidy toward the production of theatre, one on distribution and one on consumption. The different approaches to mapping are related to the cultural policy aim of securing the distribution of theatre in Denmark in different ways, which I will point to. As a part of the analysis, I will also address the methodology as well as the limits of building the mapping on exactly these three databases that, together, form the entire official statistics of Danish theatre. This has some severe limitations, not least regarding the geographical distribution.

I will begin the article with a brief introduction to the structure of the theatre system in Denmark, a prerequisite for understanding the analysis and the implications of the result of the mappings. ${ }^{1}$ After presenting the data sets used for the mapping, I will look at three different mappings, addressing which political conclusions can (or cannot) be drawn based on each of them. In the discussion, I will address the question of how to use mapping in a political context and what to be aware of as an academic when engaging in analyses of politically delicate matters.

\section{THE THEATRE STRUCTURE IN DENMARK}

My focus in the mappings concerns publicly subsidized professional theatre. The topic of regional distribution is a cultural policy debate and is thus primarily relevant in relationship to the publicly subsidized theatres.

The system of professional, subsidized theatres in Denmark consists of 1) large theatre institutions subsidized regularly by the state, 2) small theatre institutions subsidized regularly by local authorities, and 3) theatre companies without a regular subsidy subsidized by the Danish Arts Foundation. The following should give an overview:

1. Large, regularly subsidized institutions:

- The Royal Danish Theatre, Denmark's national theatre: by far the largest theatre institution in Denmark, comprising drama, opera and ballet, located in Copenhagen.

- Regional theatres: Aarhus Teater, Odense Teater and Aalborg Teater, all of which produce a broad range of performances and have a permanent ensemble, located in the three largest cities outside Copenhagen.

- The Copenhagen Theatre Cooperation (Københavns Teater): an umbrella organization for the 
five largest theatres in Copenhagen (apart from the Royal Danish Theatre), each theatre has an individual artistic profile.

- The national touring companies: The Danish National Opera (Den Jyske Opera) based in Aarhus, and folketeatret.dk based in Copenhagen (see below for details about the organizational complexity of folketeatret.dk).

- Det Ny Teater in Copenhagen: from 2012 onwards, this theatre has received a direct state subsidy from the national budget. Before this, it was part of the Copenhagen Theatre Cooperation with a small subsidy to pay the rent.

2. The smaller, regularly subsidized institutions:

- Local theatres (egnsteatre): small professional theatres located outside the four large cities (Copenhagen, Aarhus, Aalborg and Odense), and subsidized by the municipalities and the state.

- Small city theatres (små storbyteatre): small professional theatres located in the four largest cities (with Copenhagen including the municipalities of both Copenhagen and Frederiksberg), and subsidized by the municipality and the state.

3. Theatre companies without a regular subsidy:

- Theatre companies receiving funding from the Danish Art Foundation either on a project basis or on an annual basis.

All of the above categories produce theatre and most of them present it as well. This means that there is a strong link between the production and distribution of theatre in Denmark, which, in an international perspective, is worth noticing. However, the theatres do not only present their productions at their own venue. As the mapping of distribution of theatre will show, productions are also presented on tour. The level of touring varies, but for some types of theatre, the level of touring is substantial.

\section{AVAILABLE INFORMATION, TYPES OF DATA AND ANALYTICAL POSSIBILITIES}

If one is not intending to carry out the archival and detective task of digging up old annual reports from various theatres or the anthropological task of seeking out all theatrical events in a given area, a map- ping of theatre will have to be based on available sources. The advantage of using existing data is not only that it saves time, but it also increases the credibility of the analysis because the official statistics are based on standardized definitions of e.g. what is a theatre performance. The disadvantage is that you will have to accept the categorizations in the data sets as well as the limitations in the data sets. I will return to this in the discussion of each of the three mappings. For the mapping of the Danish theatres, three existing sources were chosen:

- The Ministry of Finance database to map the distribution of national subsidies for theatre. ${ }^{2}$

- Statistics Denmark to map professional theatre distribution. ${ }^{3}$ These statistics includes number of productions, performances and audiences of performing arts. ${ }^{4}$

- The national survey of cultural participation Danskernes kulturvaner - to learn more about the habits of the Danes in terms of attending theatre. $^{5}$

Since the three different mappings are based on three different sources, they are not entirely compatible, which must be reflected in the analysis. The statistics concerning production and distribution as well as subsidy are without any categorization based on geography, which means that the only possible way to analyse this is to look at the categorization of the type of institution and then the location. The mapping focuses mainly on publicly subsidized professional theatres, which are the only theatres in the Ministry of Finance database. Statistics Denmark includes non-subsidized theatres as well, but this data has a low validity. The focus on subsidized theatres and on subsidy for theatre production was also based on the fact that the report this article is based on was written for a network of professional, state-subsidized theatre companies, which made it less relevant to search for supplementary data concerning the ticket system or activities of theatre associations, for instance.

The Ministry of Finance database can be used to track national subsidies for professional theatre down to specific institutions in the case of the large institutions (account 212311); but for the smaller theatres the only available information is the total amount and the number of theatres within the na- 
tional subsidy scheme, with nothing being stated about the amount of subsidy for each theatre (account 212321). The largest problem concerning subsidy for the smaller theatre institutions is that not all small theatre institutions receive their national subsidy directly from the Ministry. These indirect subsidies are allocated through the scheme for Regional Cultural Agreements, with a four-year contract between the Ministry of Culture and one or more municipalities being drawn up including the transfer of a total sum for cultural subsidies. ${ }^{6}$ This means that the total amount of subsidy for small city theatres is not available in any national database. To compensate for this, I have supplemented the data set with additional information from the municipalities regarding the national subsidy for small city theatres given through a Regional Cultural Agreement.

The figures in accounts 212311 and 212321 only include direct production subsidy and not indirect subsidies such as the national ticketing scheme (account 212354) that enables lower ticket prices e.g. for subscribers or for young people. ${ }^{7}$ I have chosen not to include this subsidy in my calculations. First and foremost: it is not possible based on the Ministry of Finances database (or any other publicly available database) to calculate the geographical distribution of this subsidy. Secondly: the level of subsidy given via the national ticketing scheme is low (70.8 mills DKK in total (2012), only 0.7 of the total subsidy for theatre), and this subsidy is distributed to theatres both in and outside Copenhagen and thus probably does not influence the overall picture substantially.

With regard to the production and distribution of professional theatre in Denmark, Statistics Denmark has data on the activities of the professional, state subsidized theatre going back to season 1980/81. The data has been slightly amended several times, mainly caused by amendments in the Theatre Act leading to a reconfiguration of the institutional structure. One example: in 1996, the category 'local theatres' (egnsteatre) was split between 'local theatres' and 'small city theatres' because the same distinction was now drawn in the Theatre Act. The category now called the Copenhagen Theatre Cooperation has also been changed over the years, not least with regard to the number of theatres included in this category.

Consumption of theatre is included in the national survey of cultural participation. The latest was conducted in 2012 and it is a part of a series of surveys going back to 1964 . The survey is conducted irregularly and the second newest is from 2004. This is survey data based on a representative sample of the Danish population. As such it is a different type of data compared to the data in the theatre statistics and the Ministry of Finances' database.

The analysis of the conditions for theatre in the regions was conducted based on these three official sources and accordingly on three different parameters: the amount of subsidies, the production and distribution of theatre performances, and the habits of the Danish people concerning attendance at the theatre.

\section{MAPPING THE GEOGRAPHICAL DISTRIBUTION OF SUBSIDY}

The distribution of national subsidy to the production of theatre is presented in Figure $1 .^{9}$ It is based on the Ministry of Finance database and limited to the direct subsidy to theatre institutions. I have systematically categorized the theatres based on the parameter on whether the theatre is located in or outside Copenhagen. This could only be done by supplementing the information in the database with information from the municipalities (required by email) on the subsidy for small city theatres.

For one institution, it is worth discussion whether the subsidy should be calculated as a subsidy for theatre in or outside Copenhagen. This is folketeatret.dk, which is both the national touring theatre company and a part of the Copenhagen Theatre Cooperation. ${ }^{10}$ For this reason, the subsidy for the touring activities of folketeatret.dk was categorized as a part of 'the rest of the country', while the subsidy that is included in the subsidy for the Copenhagen Theatre Cooperation is categorized under Copenhagen. This resulted in the distribution presented in Figure 2.

This means that $67 \%$ of the national subsidy for theatre is given to theatres in Copenhagen. Based on this calculation, a conclusion of the mapping of 
the geographical distribution of theatre subsidy is that there is a clear disproportion, which in the last few years seems to be relatively stable. It could be argued that the subsidy for the Royal Danish Theatre should be excluded from the calculation since it has an extraordinary position in the theatre system with a clear national function and because it receives such a large proportion of the national subsidy for theatre, it is almost impossible to discuss a balanced distribution of financial support between the capital and the rest of the country. For this reason, I have included the calculation of the geographical distribution without the Royal Danish Theatre. The result of this is that $14 \%$ of the national subsidy is given to other theatres in Copenhagen, whereas the rest of the country receives $33 \%$.

But how does that relate to the distribution of people in Denmark? This might seem like a simple question, but there are different possibilities. One is to include only the citizens in the municipalities of Copenhagen and Frederiksberg in the category 'Copenhagen' (version 1). All of the theatres included in the category 'Located in Copenhagen' are situated in these two municipalities. Based on this, the calculation of the level of subsidy per inhabitant would still be higher in the capital (1020 DKK including the Royal Danish Theatre, 208 DKK excluding the
Royal Danish Theatre) than in the rest of the country (68 DKK). The only figures that could be used to argue for an even balance between Copenhagen and the rest of the country is when including the whole Capital Region of Denmark (Region Hovedstaden) (version 2) and excluding the Royal Danish Theatre. ${ }^{12}$

This first part of the mapping of the geographical distribution of subsidies for theatre in Denmark only deals with institutional support. How much weight this should have depends on which cultural policy objectives are prioritized. The geographical distribution of the subsidy for production of theatre is important, if it is a political aim to secure the accessibility and local anchoring of performing arts, which might have positive effects on the possibility of creating audience relations as well as having an artistic value. In addition, this question of geographical distribution is important in terms of jobs in the arts, a subject that can be linked in a broader perspective to the debate about centre/periphery.

\section{DISTRIBUTION OF PERFORMANCES}

The second mapping will look at the distribution of the performances. In relation to a political objective of securing access to the performing arts for

\begin{tabular}{|l|l|l|l|l|l|}
\hline & Physical location & $\mathbf{2 0 0 9}$ & $\mathbf{2 0 1 0}$ & $\mathbf{2 0 1 1}$ & $\mathbf{2 0 1 2}$ \\
\hline The Royal Danish Theatre & Copenhagen & 551.1 & 550.4 & 562.1 & 535.8 \\
\hline $\begin{array}{l}\text { The Copenhagen Theatre } \\
\text { Cooperation }\end{array}$ & Copenhagen & 116.7 & 113 & 111.8 & 108.5 \\
\hline Det Ny Teater & Copenhagen & 0 & 0 & 2.9 & 10.9 \\
\hline Small city theatres in Copenhagen & Copenhagen & 18.9 & 18.3 & 17.9 & 17.6 \\
\hline $\begin{array}{l}\text { folketeatret.dk (subsidy for touring } \\
\text { activities) }\end{array}$ & Rest of Denmark & 22.7 & 22.8 & 22.7 & 23 \\
\hline $\begin{array}{l}\text { Large institutions outside } \\
\text { Copenhagen (regional theatres and } \\
\text { the Danish National Opera) }\end{array}$ & Rest of Denmark & 206.7 & 207.3 & 210 & 208 \\
\hline Local theatres & Rest of Denmark & 86.1 & 88 & 88.6 & 89.6 \\
\hline $\begin{array}{l}\text { Small city theatres outside } \\
\text { Copenhagen }\end{array}$ & Rest of Denmark & 14.5 & 14.7 & 15.2 & 15.4 \\
\hline
\end{tabular}

Fig. 1. The distribution of national subsidy for the production of theatre. Figures in DKK million. 


\begin{tabular}{|l|l|l|l|l|}
\hline & DKK (2012) & Percentage & $\begin{array}{l}\text { Subsidy per capita } \\
\text { version 1 }\end{array}$ & $\begin{array}{l}\text { Subsidy per capita } \\
\text { version 2 }\end{array}$ \\
\hline $\begin{array}{l}\text { All theatres in } \\
\text { Copenhagen }\end{array}$ & 672,8 & 67 & 1020 & 389 \\
\hline $\begin{array}{l}\text { Theatres in } \\
\text { Copenhagen minus } \\
\begin{array}{l}\text { The Royal Danish } \\
\text { Theatre }\end{array}\end{array}$ & 137 & 14 & 208 & 79 \\
\hline $\begin{array}{l}\text { Theatres outside } \\
\text { Copenhagen }\end{array}$ & 336 & 33 & 68 & 87 \\
\hline
\end{tabular}

Fig. 2. The distribution of national subsidy.

the whole population this could be seen as the most important parameter: in order to supply the population with performances, these need to be distributed throughout the country. This part of the mapping will be based on the theatre statistics from Statistics Denmark. These data were used to make exactly this kind of analysis by the Ministry of Culture in a report from 2009. This report concluded: "In the entire period there have been more nationally subsidized performances of theatre in the capital and slightly fewer in the rest of the country. $55-60 \%$ of the nationally subsidized performances took place in the capital, and $40-45 \%$ took place in the rest of the country." 13 This information was provided by the Ministry as part of an official debate in the Parliament, which means that it, hopefully, should be a reliable and objective analysis. However, there is a need to look more carefully into these data. The calculation was based on the residential locations of the theatre companies concerned, which means that any kind of touring activity was not taken into account. Thus, in order to produce a more realistic calculation, data about the division between resi- dential and touring performances has to be included (presented in Figure 3). ${ }^{14}$

This calculation shows that between 36 and $41 \%$ of the total number of performances were presented on tour and thus explicitly not at the home venue of the theatre company. This means that the calculations made by the Ministry based on the Statistics Denmark data were at least imprecise, if not unreliable. Since there are no data regarding the location of the performances presented on tour, one can only speculate. The speculation could start like this: if it is primarily theatres in Copenhagen that go on tour, then figures would reflect the fact that a large part of the theatre production is located in Copenhagen, while the performances are actually presented throughout the country. However, if you take a closer look at the figures, this can neither be proven nor disproven. In 2011/12 the local theatres delivered $26 \%$ of the touring performances, which means that the decentralized local theatres do not only supply their local area with performing arts. Concurrently, the large theatres in Copenhagen (Copenhagen Theatre Cooperation and the Royal

\begin{tabular}{|l|l|l|l|l|l|l|l|l|}
\hline & $\mathbf{2 0 0 4 / 0 5}$ & $\mathbf{2 0 0 5 / 0 6}$ & $\mathbf{2 0 0 6 / 0 7}$ & $\mathbf{2 0 0 7 / 0 8}$ & $\mathbf{2 0 0 8 / 0 9}$ & $\mathbf{2 0 0 9 / 1 0}$ & $\mathbf{2 0 1 0 / 1 1}$ & $\mathbf{2 0 1 1 / 1 2}$ \\
\hline $\begin{array}{l}\text { Performances in } \\
\text { total }\end{array}$ & 11,233 & 10,820 & 11,275 & 10,676 & 11,970 & 12,680 & 11,717 & 11,429 \\
\hline $\begin{array}{l}\text { Performances } \\
\text { presented at the } \\
\text { venue of the theatre }\end{array}$ & 6,904 & 6809 & 7,238 & 6,865 & 7,547 & 7,498 & 7,275 & 7,234 \\
\hline $\begin{array}{l}\text { Percentage } \\
\text { presented on tour }\end{array}$ & 39 & 37 & 36 & 36 & 37 & 41 & 38 & 37 \\
\hline
\end{tabular}

Fig. 3. The relationship between performances and venues. 
Danish Theatre) have a very small proportion of touring performances: $1 \%$ and $2 \%$ of the total performances respectively. But given that $71 \%$ of the touring performances in the data set are produced by groups and theatre companies that cannot be exclusively located either in or outside Copenhagen (folketeatret.dk and the Danish National Opera (together), the small city theatres and theatres subsidized by the Arts Council), it is impossible to say anything definite about the distribution between Copenhagen and the rest of the country in relation to touring performances.

Thus, the mapping of performing arts based on the distribution of performances ends with a very modest conclusion: the lack of data also means that there is no possible way to evaluate the central cultural policy objective of securing equal access to theatre throughout the country.

\section{PERFORMING ARTS CONSUMPTION}

The analysis of the consumption of performing arts in Denmark is based on data from the national survey Danskernes Kulturvaner. This means that this analysis is not directly comparable to the two others, primarily because the survey has a very broad definition of 'theatre' that does not only include both subsidized and non-subsidized theatre, but also both professional and amateur performances as well as genres like stand up-comedy and street performances. Seen from a cultural policy perspective, this might be the most important mapping: the one investigating whether or not citizens have an equally high theatre-going participation rate regardless of where in the country they live.

Two different aspects related to geography from Danskernes Kulturvaner were included in the analysis. One about the significance of geography for participation and participation patterns, and one related to where the population goes to the theatre. The significance of geography for participation included two different variables: region and urbanization. With regard to regional differences, the report concluded that there were no major differences between the different regions overall. ${ }^{15}$ This might be caused by the fact that there are only five different regions in Denmark, all of which include one large city. The variable that made a difference was urbanization: In rural municipalities, $29.4 \%$ of the population never attend any kind of theatre, while the corresponding number in urban municipalities is only $13.5 \%$. The conclusion in Danskernes kulturvaner regarding the correlation between geography and consumption was that "consumption of the different forms of theatre reflects opportunities and supply in the different regions". ${ }^{16}$ The survey also documented that going to the theatre is mainly an activity that takes place locally, which means that the geographical imbalance in theatre consumption can only be changed by the availability of theatre throughout the country.

\section{DISCUSSION}

Taken together, the three mappings include the three main perspectives on the geographical distribution of theatre in society (production, distribution and consumption), and point towards the main cultural policy objectives of each, as such mappings can be seen as an important input in the cultural policy debate on decentralization. This was the case with the analysis made by the Ministry of Culture, but also with the report Conditions for Theatre in the Regions (Vilkairerne for den regionale scenekunst) that was the original context for the calculations presented and discussed in this article. There are, of course, limitations on the types of analysis in which mapping is a suitable approach, but that might not be the most important consideration regarding the use of mapping as an analytical strategy, especially not when addressing delicate political questions such as decentralization and the distribution of (scarce) public resources for theatre. What seems more important is the discussion of the methodological choices made regarding not only choice of data set and the limitations of this, but also the way the calculations are made and the perspective that gives on the issue debated. The reason why this is perhaps even more relevant to discuss in relation to this article is the fact that mapping appears to be a neutral and non-political way of analysing. It is based on figures, which are presented in an apparently neutral and objective way. However, the very fact that the three different mappings showed dif- 
ferent pictures of the balance between the capital and the rest of the country means that they have different implications in a cultural policy context.

The clearest example of this is mapping 1 about the distribution of public subsidy. If the calculation excluded the Royal Danish Theatre and included inhabitants in the entire Capital Region of Denmark, the distribution was balanced, but calculations based on the citizens in the municipalities of Copenhagen and Frederiksberg showed another picture and with the Royal Danish Theatre included, there was a severe imbalance.

The discussion is not just whether or not this balance is fair or just, but also whether or not this balance is important. If the second mapping of the distribution of performances had shown another picture, then the balance between the capital and the rest of the country would have merely shown that theatre was produced centrally but presented decentralized - as it e.g. is the case in the Dutch theatre system. ${ }^{17}$ However, the second mapping turned out to be inconclusive because of the limitations of the data set. The third mapping opened up for yet another perspective on the question of regional distribution of theatre; that of consumption. This included not only professional subsidized theatre, but also amateur and commercial theatre, and it opened up a new perspective: that it might not just be relevant to discuss the balance between the capital and the rest of the country, but the difference between urban and rural areas, where the significant differences existed.

My point would be that none of the three approaches is more correct than the other. Furthermore, as Jørn Langsted has commented: "Different figures may technically speaking be correct, but whether or not they are correct in a further sense depends on the context in which they are used." 18 Because of this, it is an important part of the responsibility of the researcher to state carefully the limitations of figures and the conclusions that are based upon them.

Living up to academic standards when engaging in political debates, however, includes more than just meticulous reporting of reservations and implications of the methods and data set chosen. It also includes a clear pointing towards the political implications of the mappings. When analysing the geographical distribution of theatre in Denmark, you are analysing an issue of political relevance. The role of the academic is not to point towards the right balance, because that is a political question. And what is the right balance? If the objective is a completely even distribution of subsidies for the performing arts, the result would be that geography would become the most important cultural policy criteria. The consequence of this would be that subsidies for the performing arts would be granted without looking at artistic quality, the distribution of genres, and historical factors such as the location of existing theatre companies and venues. No-one thinks that this is a reasonable approach to performing arts policy. The starting point for the analysis is, thus, that there is no way to ensure an objective and fair distribution of resources. However, this does not mean that the issues of balance and fairness cannot be analysed and discussed. As a researcher, I find it necessary to explicitly state the political implications of my analysis and to point towards the (obvious) fact that any political consequences drawn from the report are necessarily political. This means that the arguments and recommendations tend to be based on the formula: 'if the politicians want this, then they should consider that'. 'This' is defined as the values and objectives that some stakeholders within the cultural field want to promote. In this way, the academic contribution to the political debate is not to argue for any specific agenda, but to make sure that arguments can be based on thorough analyses in which the limitations of the conclusions are transparent. 


\section{NOTES AND REFERENCES}

1 The article is based on the report: Louise Ejgod Hansen, Vilkair for den regionale scenekunst (Conditions for Theatre in the Regions), Scenekunstnetværket Region Midtjylland, Randers 2013. The report was commissioned by Scenekunstnetværket Region Midtjylland (SceNet - the Theatre Network in Central Denmark Region), a network of professional theatres in the Central Denmark Region. For SceNet the aim of the research was to provide a stronger evidence base for the debate about the geographical balance and the prioritisation of decentralisation of theatre in Denmark. The methodological choices in the analysis were mine alone, as well was the conclusions drawn.

2 http://www.oes-cs.dk/olapdatabase/finanslov/index.cgi (accessed 13 October 2015). The information regarding subsidy for theatre is a part of the expenses of the Ministry of Culture. In the chart of account the relevant accounts are 2123 , below this specifically 212301,212311 and 212321.

3 http://www.statistikbanken.dk/statbank5a/default. asp?w=1440 (accessed 13 October 2015).

4 In Denmark it is now common to use the term 'performing arts' instead of theatre. This term covers drama, dance, physical performance, etc., but not live music.

5 Pluss Leadership, Epinion, Danskernes kulturvaner 2012 (The Cultural Habits of Danes, 2012), Kulturministeriet, Copenhagen 2012. Pluss Leadership, Epinion, $T a-$ belrapport. Teater og anden scenekunst, Kulturministeriet, Copenhagen 2012.

6 Kulturministeriet, Bekendtgørelse af lov om Kulturministeriets kulturaftaler med kommuner m.v. og om regionernes opgaver på kulturområdet, Ministerial order no. 728 of 7/6 2007, https://www.retsinformation.dk/Forms/ R0710.aspx?id=12061 (accessed 13 October 2015).

7 Kulturministeriet, Bekendtgørelse om formidlingstilskud til nedbringelse af billetpriser, Ministerial order no. 30 of 14/01/2014 \$24, https://www.retsinformation.dk/ Forms/R0710.aspx?id=144278 (accessed 13 October 2015).

8 The inclusion of more than one year in the table is only meant to demonstrate that this is a stable situation with just minor changes. The time span of the data included is not long enough to investigate the historical development. That could be both relevant and interesting, but is not the purpose of this article.
9 This is a result of a merging of the former national touring company Det Danske Teater and Folketeatret in 2007. For this reason the subsidy to this theatre is still split into two in the Financial Act: one categorised as part of the general subsidy to the Copenhagen Theatre Cooperation, and the other categorised as a subsidy designated to the touring activity. It is problematic to regard the second part of this subsidy as designated to theatre in Copenhagen based on its location, because the aim of this institution is to provide theatre all over Denmark.

10 But in this case, one should remember that the calculation of level of subsidy for theatres outside Copenhagen also includes theatres located in the Copenhagen Region, outside the municipalities of Copenhagen and Frederiksberg.

11 Kulturministeriet, Faktuel redegørelse om teatersituationen i Danmark 2004/2005 - 2007-2008, Kulturministeriet, Copenhagen 2009, p. 49.

12 Statistics Denmark, Opforelser på statsstottede teatre efter teater og type (1981/82-2013/2014), http://www.statistikbanken.dk/statbank5a/default.asp?w=1440 (accessed 12 October 2015).

13 Pluss Leadership, Epinion, Tabelrapport, op. cit., p. 156.

14 Pluss Leadership, Epinion, Danskernes kulturvaner 2012, op. cit., p. 47.

15 Hans van Maanen, "The Dutch Theatre System: A World of Independents" in Theatre Research International, vol. 27, no. 2, 2002.

16 Jørn Langsted, "Tal om kultur" in Indfald og udfald. Kulturpolitiske analyser, Klim, Aarhus 2005, p. 58. 
